\title{
Training Program Supporting Language Acquisition
}

\author{
Hatice Yalcin \\ KTO Karatay University, Department of Child Development, Konya, 42200, Turkey \\ Email: hatice.yalcin@karatay.edu.tr \\ Murat Demirekin \\ Private Academy BLC English Course, Konya, 42200, Turkey \\ Email: mdemirekin@gmail.com
}

Received: 05 March 2021; Accepted: 19 April 2021; Published: 08 June 2021

\begin{abstract}
This study was conducted to evaluate the effects of a parenting training program that supports language acquisition in early childhood. To reveal such an effect, an experimental research design including pre-test-post-test and retention test was applied respectively. Experimental and control groups were formed with the parents of 4-6 years old children attending pre-school education institutions. To assess the language development levels of the children, Peabody Picture-Vocabulary Test (PPVT) was applied during the pre-test phase; after the parental training, a post-test was applied; and a year later, a retention test was implemented alternately. Parents in the experimental group evaluated the program after the Parental Support Program (PSP). The personal characteristics of the study group and the opinions of the parents evaluating the training have been shown by using the frequency and percentages. Whether PPVT and PSP scores differ according to socio-demographic variables was analyzed by t-tests. In the end, there was a significant increase in the results of the post-test and retention test performed after parent training that supports language acquisition. This increase has been found to be significantly higher than the PPVT scores of children in the control group. Thus, we have determined that the parents have a positive attitude towards the training program. The results of the study also reveal that parenting training that supports children's language acquisition has a positive effect on children's language development.
\end{abstract}

Index Terms: Language acquisition, parental training, Peabody Picture-Vocabulary Test, early childhood.

\section{Introduction}

In all fields of science; Language should be used correctly in order to transfer scientific studies and to reach information. Language is important in the cognitive and social behavior of all people. Language is universal. Language is used for the purpose of interaction throughout people's life. In order to transfer engineering, mathematics or social sciences to people, language must be used correctly [1,28]. Language is not just about a nation or race, it is necessary for all people to convey knowledge. Language acquisition also takes place in the family environment. Language acquisition should be provided in the family environment in order to reach information. For this reason, it is important to educate family members about how to acquire language. In this research, a program supporting language acquisition was developed, and the effects of this program on language acquisition were examined [1,2].

While humans acquire language, their first models are their parents, other family members, and then other individuals with whom they interact in the social and school environment. With an effective educational program to be implemented in the pre-school period, when basic concepts begin to emerge, the acquisition and reinforcement of the expected skills will make remarkable contributions to the child's following educational life [4,27].

Parents or other caregivers are the children's first teachers. Teaching to speak continues throughout life in the family environment. Parents need to provide an environment that aids their children's language acquisition at school.

For a healthy language development process, an adult model that informs the child, motivates him/her for thinking, and expands the vocabulary is required considerably. Although there are not sufficient programs that support parents in Turkey regarding the language acquisition of the child, the level of development cannot be laid down clearly because the retention test is not performed in existing programs. Thus, it seems important to carry out a study that investigates the retention or permanence of parents' influence on language acquisition of pre-school children [5,11,29].

Studies show that parents' involvement in language acquisition affects children's social, emotional, psychological and interactional development $[5,9,13,22,27]$. Parents' involvement in language acquisition requires participation in 
partnerships such as parent-child, parent-teacher, and parent-parent. Education of parents is necessary to increase the success of their children in accessing information, conducting research and maintaining social interaction [2,12].

Parents in Turkey are not involved in the education process on language acquisition. Policies supporting the education of parents on language acquisition are inadequate in the national education curriculum. Parents believe they can make a significant difference to their children's education; however, they do not actively participate in the process. However, some studies show that parents are the most important factor affecting children's language acquisition $[11,12,15]$.

The number of studies involving parents in the language acquisition of their children is insufficient. Parents are taught that they can contribute to language acquisition by just giving brochures, posters or lectures [11,15]. Education programs that ensure permanent learning of children are inadequate. However, language acquisition should be provided to children through interactive methods such as games, brainstorming, case study, case study. In this research we conducted, these interactive methods were taught to parents.

It is expected that "parent training techniques that support language acquisition" used in this study will serve as a model for educators in Turkey. The techniques of this research, in which the participation of teachers are also supported, will be a model for other studies in Turkey.

This study was conducted to identify the effect of a Parental Training Program that supports language acquisition in early childhood. In line with this main purpose, evaluations were realized within the framework of the following research questions:

-What is the level of language skills in children in early childhood?

-What is the effect of a parental training that supports children's language acquisition in early childhood on children's language scores?

-How is the parenting training program that supports language acquisition evaluated in terms of content, instructor, material, goal, and method criteria?

-If parents support their children in language acquisition, will it be permanent?

-If parents are trained in language acquisition, what is the impact on children?

\section{Literature Review}

Language is a complex and dynamic system of symbols that people use to interact with each other, to convey their thoughts and to organize their social behaviors. People also use a language to understand and to interpret a society's cultural heritage values. Language is of great importance in the transfer of cultural characteristics and social values to future generations. From their birth on, children use the language they acquire as a tool to communicate with their circles, comprehend events, get to know society, and take part in society as individuals $[3,4,5]$.

Today, globalization has increased the importance of language learning from an early age. The foundations of language use skills are laid in early childhood. Concepts such as children's comprehension of language and language acquisition have become an increasingly important issue day by day, thanks to the further concentration of studies and the improvement in knowledge in this field. Beginning from the pre-school period, activities related to the acquisition of foreign languages are fulfilled in schools and the number of institutions that teach a different language other than the mother tongue is increasing considerably [3,5].

Children acquire a language by listening to adults, imitating them, and sharing what they learn with them [6]. Early childhood is a critical period in terms of language acquisition and the development of language skills, as the foundations of skills required for language are laid in early childhood [4]. Language development is not the same in all children. The early stages of language development in the children of various communities speaking different languages may have similar characteristics; however, generally after the 18th month, language acquisition varies with the differentiation of the child's social environment [5,7,8]. Children are born with similar language skills, but their ability to learn language deteriorates when they do not receive sufficient vocal stimuli for their development, as in those with hearing impairments [9]. Children cannot learn to speak in a non-speaking environment [10]. Parents' conversation with a child is a fundamental model in the development of a child's speech function [11]. In the first years of his/her life, a child considers the parents as role models at home in the language development process. For this reason, it is of great importance that parents be a model for their children with their words and behaviors in the home environment. Therefore, parental support has a remarkable role in the development of a child [12].

Before learning to speak, children find out that communication has many purposes and serves to meet a wide range of social, emotional, and practical needs. The preverbal period is a universal stage through which all children live for communication. A diverse and rich interaction in this period will form the basis of an effective and satisfying communication later on [15]. In the first months after birth, a baby starts to imitate the sounds he/she hears from the outside while making some sounds such as crying, babbling, hiccups, and shouting [11].

The child's understanding of what is spoken and starting to speak takes place after certain stages such as sound imitations, syllable repetitions, and uttering the first word respectively. As the child matures, his / her control over speech increases, and the effect of the environment and education on his / her development gains importance [12]. In 
the early period, based on their natural curiosity, children constantly tend to interact with the stimuli around them. Such a sense of curiosity leads them to research, observe, and question as well [14]. Early childhood is considered to be a "critical" or "crucial period" in terms of language acquisition [15]. Before the age of six or seven, children generally go through the acquisition stage of a language, not through learning the language [16]. In this acquisition phase, until the brain matures and the cognitive mechanisms are ready for the learning phase, they have the ability to naturally acquire the language they come into contact by employing of a process similar to that of native language acquisition. After this age, the "learning" phase is initiated which subsequently brings about other advantages to the learner [17].

Children's language acquisition has been studied in various dimensions by researchers of different theories. Each theory explains the acquisition of language from its own perspective. According to the behaviorist theory, language development occurs with completely observable behaviors $[4,11,18]$. This approach claims that language acquisition occurs when a child imitates speakers and just after the adults around reward or reinforce this behavior. When elaborating on language acquisition, the pioneers of the behaviorists Watson and Skinner state that the sounds made by children by chance are created by the repetition of the sounds in their mother tongue. When the child reacts positively, he/she repeats these sounds; and over time it gradually becomes a habit to make these sounds $[2,19]$.

According to Chomsky, a child's innate language ability develops spontaneously as a result of interaction with the environment. Thus, a child learns the structure of his/her mother tongue by matching the features of the language he/she interacts with, via the grammar rules readily available in his/her mind. According to this view, a language seems to develop independently from intelligence and other cognitive processes [20]. Within the framework of the Piaget's interactionist theory, he emphasizes the interaction of biological and environmental factors in language development [21]. The language development of a child is affected by the language use of the family that firstly communicates with him/her [22]. For a child's language acquisition and the development of vocabulary, parents need to know the strategies of using language and teaching. Learning a language for the child means learning to think because thinking is revealed as the product of language [23]. The effect of parents on cognitive processes such as thinking and speaking continues throughout a child's life [16].

Khamkhie (2010) argues that a child's perception of the external world and interacting with it is related to his/her cognitive development and suggests that the cognitive process will develop faster with the child's active interaction [13] The unique factor that provides this interaction is said to be language acquisition. Vygotsky (1998) states that a language helps children think about their own behaviors; he also points out that a child learns words by memorizing, recalling, and classifying them respectively [14].

Language plays an important role in the cognitive and perceptive development of a child. The child begins to acquire language skills as soon as he/she is born. For this reason, it is very beneficial to notify parents in advance so that the child can achieve healthy language development [24,25]. While children acquire language, their first models are their parents, other family members, and then other individuals with whom they interact in the social and school environment. With an effective educational program to be implemented in the pre-school period, when basic concepts begin to emerge, the acquisition and reinforcement of the expected skills will make remarkable contributions to the child's following educational life [26].

\section{Method}

This study was conducted to evaluate the effect of a Parenting Training Program that supports language acquisition in childhood.

For the validity and effectiveness of the research method, firstly the previous studies were reviewed. It was determined why the methods used were not effective. The method prepared for this research was prepared with the approval of the faculty members at three different universities. The "Peabody Picture-Word Test" and "Attitude Scale towards Parenting Training Program" used in the study are scales with proven validity and reliability (detailed validity and reliability features are given under the title of "Data Collection Tools") [32,34]. For this purpose, the experimental research design of the pre-test-post-test was applied. In this design, the cause and effect relationship is examined between variables. The independent variable is manipulated through an mean processe unbiased assignment and the external variables are taken under control. Within the scope of the design, two groups available are matched according to certain variables [30].

In the study, firstly the experimental and control groups were determined, and measurements were fulfilled before and after the experiment in both groups. Pre-testing allows the groups to perceive the degree of similarity before the experiment and to correct the post-test results accordingly [31]. After obtaining official permissions from the relevant Ethics Committee and the institutions where the study will be conducted, a meeting was held, and detailed information was given to the parents and teachers. Randomized experimental and control groups were formed with parents who voluntarily accepted to participate in the study.

Parent Education Program in Language Acquisition was prepared by the researchers. In this program, there are language activities such as poetry, story, finger games and conversation. At the same time, there are activities that support mental and cognitive skills such as finding the different, painting, and experimenting. In the Parent Education Program, the topics were distributed homogeneously throughout the education process, and different activities were 
held each week. Activities have been planned for children and parents to have quality and enjoyable time. Before starting the Language Development Supporting Parent Education Program, a meeting was held with the parents of the experimental group children by the researchers. The activities were carried out under the supervision of the parents, and were implemented at times when the child and parents could spend the most comfortable time. All these planning facilitate children's language acquisition. Peabody Picture-Vocabulary Test (PPVT) was applied in the pre-test to determine the language development levels of the children. An eight-week Parental Support Program (PSP) was implemented by detecting a calendar that fits the parents in the experimental group. PSP is an educational program that supports language development and includes language activities that children can practice with their parents at home. At the end of PSP, which lasted for eight weeks, PPVT was applied to the children in two groups in the post-test, and the Attitude Scale towards Parental Training Program was applied to the parents. When the children in the experimental group started the first grade of primary school, retention tests were also performed to measure whether the program had a permanent effect on children. The experimental design used in the study is shown in Table 1.

Table 1. Research design

\begin{tabular}{cccccc}
\hline Group & Assignment & Pre-test & Process & Post-test & Retention test \\
\hline Experimental group & Randomly & $\mathrm{O}_{1.1}$ & $\mathrm{X}$ & $\mathrm{O}_{1.2}$ & $\mathrm{O}_{1.2 .3}$ \\
\hline Control group & Randomly & $\mathrm{O}_{2.1}$ & - & $\mathrm{O}_{2.2}$ & $\mathrm{O}_{2.2 .3}$ \\
\hline
\end{tabular}

In the table of the research design, $\mathrm{O}_{1.1}, \mathrm{O}_{1.2}$, and $\mathrm{O}_{1.2 .3}$ refer to pre-test and post-test-retention test measurements of experimental groups; $\mathrm{O}_{2.1} \mathrm{O}_{2.2}$ and $\mathrm{O}_{1.2 .3}$ show the pre-test-post-test-retention measurements of the control group. No action was implemented for the control group, but the training program $(\mathrm{X})$ was applied to the experimental group. Figure 1 shows the process applied in the research design.

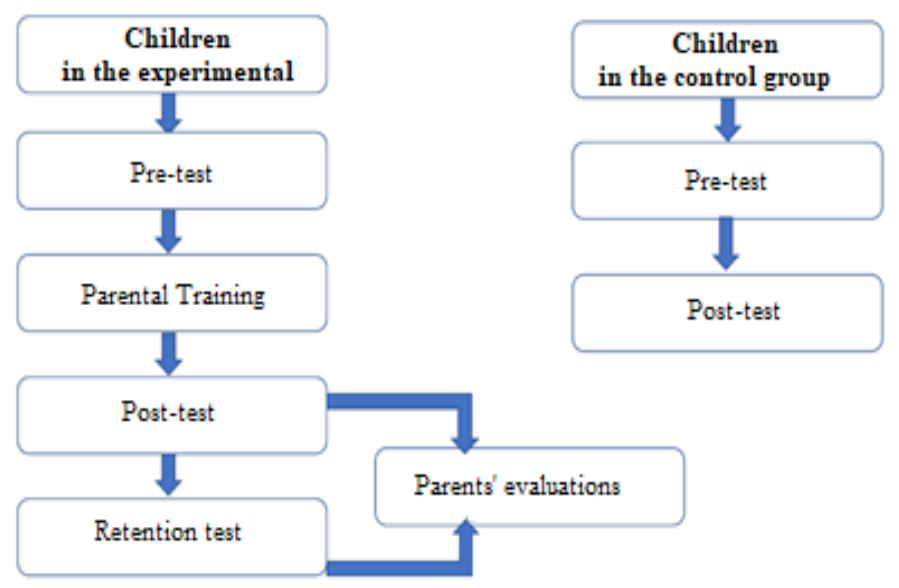

Fig.1. The process applied in the research design

While structuring the sessions of the PSP, the relevant literature was investigated in detail, the theoretical foundations of the program were determined, and the modules were prepared by considering the demographic variables of the experimental group. The contents of the PSP were rendered simple and fun enough so that the participants could easily understand, and the topics were enriched with case studies. First of all, the objectives were clarified and the knowledge and skills to be gained to the participants were determined respectively. Later, eight modules were prepared for children, including language acquisition techniques in the most permanent, accurate, and fun way, in which parents will participate interactively. The process was carefully planned. 8 weeks of training was given to the experimental group. Twice a week and 60 minutes of training were held each time. Games that increase parent-child interaction and language acquisition at home were recommended every day. Weekly homework was given to parents and children "together". The same training was given to teachers. Teachers did motivating activities that support parents every day. Feedback was received from parents and teachers each week, and new fixes and additions were made to the program based on their recommendations. In the last week of the program, teachers and parents were post-tested.

\section{Study group}

The study group in the research consists of 4-6-aged children and their parents in four pre-school institutions affiliated to the Ministry of National Education in the city center of Karaman. Relevant data of the study group are shown in Table 2 and Table 3. 
Table 2. Socio-demographic characteristics of the children in the study group $(\mathrm{N}=69)$

\begin{tabular}{|c|c|c|c|c|c|}
\hline & & \multicolumn{2}{|c|}{ Experimental group $(n=34)$} & \multicolumn{2}{|c|}{$\begin{array}{l}\text { Control group } \\
\qquad(n=35)\end{array}$} \\
\hline \multicolumn{2}{|c|}{ Socio-demographic variables } & $\mathrm{f}$ & $\%$ & $\mathrm{f}$ & $\%$ \\
\hline \multirow[t]{2}{*}{ Gender } & Female & 18 & 52.9 & 17 & 48.5 \\
\hline & Male & 16 & 47 & 18 & 51.4 \\
\hline \multirow[t]{3}{*}{ Age } & 4 & 9 & 26.4 & 8 & 22.8 \\
\hline & 5 & 12 & 35.2 & 14 & 40 \\
\hline & 6 & 13 & 38.2 & 13 & 37.1 \\
\hline \multirow[t]{3}{*}{ Number of Siblings } & Single child & 10 & 29.4 & 8 & 22.8 \\
\hline & 2 siblings & 19 & 55.8 & 18 & 51.4 \\
\hline & $3+$ siblings & 5 & 14.7 & 9 & 25.7 \\
\hline \multirow{2}{*}{$\begin{array}{l}\text { Pre-school education } \\
\text { duration }\end{array}$} & Less than 3 months & 12 & 35,2 & 16 & 45.7 \\
\hline & More than 3 months & 22 & 64.7 & 19 & 54.2 \\
\hline
\end{tabular}

$52.9 \%$ of the children in the experimental group are girls, $38.2 \%$ of them are 6 years old, $55.8 \%$ are two siblings, and $64.7 \%$ of them have attended pre-school for more than three months. $51.4 \%$ of the children in the control group are male; $40 \%$ are 5 years old; $51.4 \%$ of them are two siblings and $54.2 \%$ have been studying at a pre-school institution for more than three months.

Table 3. Socio-demographic characteristics of parents in the study group $(N=69)$

\begin{tabular}{|c|c|c|c|c|c|}
\hline & & \multicolumn{2}{|c|}{ Experimental group $(n=34)$} & \multicolumn{2}{|c|}{ Control group $(n=35)$} \\
\hline \multicolumn{2}{|c|}{ Socio-demographic variables } & $\mathrm{f}$ & $\%$ & $\mathrm{f}$ & $\%$ \\
\hline \multirow[t]{2}{*}{ Mother's age } & Younger than 25 & 6 & 17.6 & 5 & 14.2 \\
\hline & Older than 25 & 28 & 82.3 & 30 & 85.7 \\
\hline \multirow[t]{2}{*}{ Father's age } & Younger than 25 & 4 & 11.7 & 5 & 14.2 \\
\hline & Older than 25 & 30 & 88.2 & 30 & 85.7 \\
\hline \multirow[t]{4}{*}{ Mother's education level } & Primary School & 5 & 14.7 & 6 & 17.1 \\
\hline & Secondary School & 5 & 14.7 & 5 & 14.2 \\
\hline & High School & 14 & 41.1 & 16 & 45.7 \\
\hline & University & 10 & 29.4 & 8 & 22.8 \\
\hline \multirow[t]{4}{*}{ Father's education level } & Primary School & 0 & 0 & 0 & 0 \\
\hline & Secondary School & 4 & 11.7 & 6 & 17.1 \\
\hline & High School & 19 & 55.8 & 20 & 57.1 \\
\hline & University & 11 & 32.3 & 9 & 25.7 \\
\hline \multirow[t]{2}{*}{ Duration of marriage } & Less than 5 years & 5 & 14.7 & 5 & 14.2 \\
\hline & More than 6 years & 29 & 85.2 & 30 & 85.7 \\
\hline \multirow[t]{3}{*}{ Type of Family } & Nuclear family & 28 & 82.3 & 29 & 82.8 \\
\hline & Extended Family & 3 & 8.8 & 4 & 11.4 \\
\hline & Broken family & 3 & 8.8 & 2 & 5.7 \\
\hline
\end{tabular}

$82.3 \%$ of the mothers and $88.2 \%$ of the fathers in the experimental group are over 25 years old; $41.1 \%$ of mothers and $55.8 \%$ of fathers are high school graduates; $85.2 \%$ of the parents have been married for more than six years and $82.3 \%$ live as a nuclear family. When the control group is identified, one can see that $85.7 \%$ of mothers and fathers are older than 25 years old; $45.7 \%$ of the mothers and $57.1 \%$ of the fathers are high school graduates; $85.7 \%$ of parents have been married for more than six years; $82.8 \%$ of them live in nuclear families.

\section{Data Collection Tools}

Personal Information Form, Peabody Picture-Vocabulary Test, and Attitude Scale towards Parental Training Program were applied to the study group.

Personal Information Form: The children included in the study and their parents' genders, ages, number of siblings, duration of school attendance, and socio-demographic information such as parents' age, education level, length of the marriage, family type were included in the form.

Peabody Picture-Word Test: This test was first developed by Dunn (1959) [32] to determine the receptive language development of children; and it was adapted for children in Turkey by Katz, Önen, Demir, Uzunkaya, and Uludag (1974) [33]. The test is used to measure the vocabulary knowledge of children between the ages of 2-12. The application of the test takes an average of 10-15 minutes. The test consists of 100 cards and registration forms, each consisting of four images in order from simple to complex. By uttering a word for each card, the child is asked to show the appropriate one of the four images on the card or point to the number under the appropriate image. There are images of people, things, and animals on the cards used in the test. Each correct answer of a child refers to one point. The test is conducted with a single child in a quiet room without any special preparation in advance. The child is not criticized for wrong answers; if the child ever asks "Did I say it right?" the response should be "what you gave was a good answer." The real words in the test should not be told to the child, should not be used in sentences, and their meanings should not be explained. If the examinee child constantly changes his/her answer, the first thing he/she said is considered as valid. 
When starting the test for children under the age of eight, the examiner starts with "We will play a game with you", the child replies by pointing to each picture on the page.

Attitude Scale towards Parenting Training Program: In this form, there are questions about parents' evaluation of the training that is supposed to enhance their children's language acquisition. Developed by Arı, Deniz, Erişen, and Çeliköz (2006) [34], the scale is evaluated in terms of five following dimensions of the program: "objectives, content, equipment, method, and instructor". There are 25 attitude statements about the training program. In this study, additional validity and reliability studies were conducted for this scale, and the Cronbach Alpha reliability coefficient was found to be 0.86 .

\section{Analysis of Data}

The data collected from the research group were analyzed using the SPSS 26.0 statistical program. Personal characteristics of the group according to various factors and parents' opinions that evaluated training have been given using frequency and percentage. Whether the Peabody Picture-Vocabulary test scores differ according to sociodemographic variables was tested via the t-tests. Interpretations were realized based on the frequency and percentage scores presented in descriptive tables and observed in cross tables. The significance level was adopted as 0.05 in statistical comparisons.

\section{Results}

In this section, the findings of the questionnaires applied to the children and their parents in the study group according to demographic variables are presented in tables. The t-test analysis results of the Peabody PictureVocabulary Test (PPVT) scores of the children in the study group according to gender and number of siblings are shown in Table 4.

Table 4. T-test results of PPVT scores of children in the study group according to gender and number of siblings

\begin{tabular}{ccccccc}
\hline & & $\mathrm{n}$ & $\mathrm{x}$ & $\mathrm{S}$ & $\mathrm{t}$ & 0.016 \\
\hline Gender & Female & 18 & 6.04 & 1.24 & 0.94 \\
& Male & 16 & 5.86 & 1.02 & 0.114 \\
\hline Number of & Only child & 10 & 4.88 & 2.04 & 1.98 & \\
Siblings & 2 siblings & 19 & 5.24 & 1.58 & \\
& $3+$ siblings & 5 & 6.04 & & \\
\hline
\end{tabular}

The averages of PPVT test scores were compared regarding gender and number of siblings, and we observed that the difference between language development scores was not statistically significant ( $p>0.05)$.

The significance of the difference between the PPVT pre-testing scores of the children in the experimental and control groups was analyzed by an independent t-test. The values obtained are given in Table 5.

Table 5. Difference between PPVT pre-test scores of children in the experimental and control groups

\begin{tabular}{cccccc}
\hline & $\mathbf{n}$ & $\overline{\mathbf{x}}$ & $\mathbf{S}$ & $\mathbf{p}$ & $\mathbf{1}$ \\
\hline Experimental & 34 & 21.06 &,- 428 & \\
\hline Control & 35 & 19.88 & 9.02 & \\
\hline $\mathrm{p}<0.01$ & & & & \\
\hline
\end{tabular}

According to Table 5, the PPVT pre-test mean of the program score of the children in the experimental group was found as 21.06, and the PPVT pre-test mean score of the children in the control group was 19.88 ( $\mathrm{p}<0.01$ ). The fact that the pre-test scores of the children in the experimental and control groups are close to each other shows that the groups are similar in terms of language skills. These results show that there is no significant difference between the PPVT pretest scores of the children in the experimental and control groups.

The distribution of the mean scores obtained by the children in the experimental and control groups in pre-test and posttest applications is presented in Table 6.

Table 6. Distribution of the pre-test and post-test mean scores of the experimental and control groups

\begin{tabular}{lcccc|cccc}
\hline & \multicolumn{3}{c}{ Pre-test } & & \multicolumn{3}{c}{ Post-test } \\
\hline Groups & $\mathrm{n}$ & $\overline{\mathrm{x}}$ & $\mathrm{ss}$ & $\mathrm{t}$ & $\mathrm{n}$ & $\overline{\mathrm{x}}$ & $\mathrm{ss}$ & $\mathrm{t}$ \\
\hline Experimental & 34 & 53,6 & 4,22 & 1,864 & 34 & 82,2 & 4,26 & 1.846 \\
\hline Control & 35 & 52,2 & 4,06 & 1,706 & 35 & 56,4 & 3.84 & 1.638 \\
\hline
\end{tabular}


While the PRVT pre-test average score of the children in the experimental group was 53.6; after the training applied to the parents, the post-test average increased to 82.2. In this case, one can claim that after the implementation of the training program for parents who support children's language development, such support provided by the parents has been revealed to have important benefits. It is understood that every achievement envisaged as a result of the training program for parents has been reflected positively on children. In other words, we may state that the support that parents give to children for language acquisition is beneficial for children.

Approximately ten months after the parents of the children in the experimental group were trained, PRVT was applied to the same children again in order to perform the Retention Test (RT) when the children started primary school. Three children in the experimental group, who were 34 children at the beginning, could not be taken into consideration because their families were in another city due to their appointment issues. The comparison of post-test and RT scores is shown in Table 7.

Table 7. The comparison of post-test and RT scores

\begin{tabular}{ccccccc}
\hline Groups & & $\overline{\mathrm{x}}$ & $\mathrm{Sd}$ & $\overline{\mathrm{x}}_{1}-\overline{\mathrm{x}}_{2}$ & $\mathrm{Sd}$ & $\mathrm{t}$ \\
\hline Post-test & 34 & 82.2 & 4.86 & 25.56 & 29 & 9.468 \\
& & & & & & \\
\hline Retention Test & 1 & 91.8 & 5.04 & & \\
\hline * $<0.05$ & & & & & & \\
\hline
\end{tabular}

One year after the post-test, PPVT was applied to the children in the experimental group, thus the difference between the post-test and RT results was identified respectively. Post-test score mean has been revealed as $\overline{\mathrm{x}}=82.2$ and RT mean score measuring the effect of their parents' attitudes towards language acquisition after one year was $\bar{x}=91.8$. This difference between the post-test-RT scores of the children in the experimental group was found to be significant at $\alpha=0.05$ level $[\mathrm{t}=9.468, \mathrm{p}<0.05]$.

The opinions of the parents in the experimental group about the content, implementation, and processes of the program were determined through the Training Evaluation Form. Descriptive statistics results regarding parents' evaluation of the training program that enhances the language acquisition of the children in the experimental group are given in Table 8 .

Table 8. Descriptive statistics results regarding the evaluation of the training program by the parents in the experimental group

\begin{tabular}{ccccccccc}
\hline & & & & & & \multicolumn{2}{c}{ Positive feedback } \\
\hline Sub-dimension & $\begin{array}{c}\text { Number of } \\
\text { items }\end{array}$ & $\mathrm{n}$ & $\overline{\mathrm{x}}$ & $\mathrm{ss}$ & $\mathrm{Min}$ & $\mathrm{Max}$ & $\mathrm{f}$ & $\%$ \\
\hline Trainer & 3 & 34 & 19.23 & 1.04 & 20.00 & 25.00 & 32 & 94.1 \\
\hline $\begin{array}{c}\text { Materials \& } \\
\text { equipment }\end{array}$ & 7 & 34 & 18.03 & 1.72 & 19.00 & 23.00 & 29 & 85.2 \\
\hline Method & 9 & 34 & 20.35 & 2.32 & 18.00 & 22.00 & 30 & 88.2 \\
\hline Content & 2 & 34 & 19.82 & 1.06 & 19.00 & 23.00 & 31 & 91.1 \\
\hline Target & 4 & 34 & 17.72 & 1.34 & 18.00 & 23.00 & 29 & 85.2 \\
\hline Total score & 25 & 34 & 95.15 & 1.49 & 84.00 & 116.00 & 34 & 100 \\
\hline
\end{tabular}

When the general evaluations of the training program applied to the parents are examined, the lowest score of the parents has been found as 84.00 and the highest score is 116 . The general evaluation average of the parents has been determined to be 95.15 . When this value is evaluated with the scores that can be obtained from the scale, it means "I totally agree" (5); in other words, it shows that the parents have had a positive attitude towards the training program implemented.

\section{Discussion}

This study was conducted to evaluate the effect of a Parenting Training Program that seems to strengthen language acquisition in early childhood. The proposed method is different from the methods used in other studies. The method was very effective as parents were also included in the study and homeschooling continued.

$41.1 \%$ of the mothers and $55.8 \%$ of the fathers who participated in this study were high school graduates. Parents with a high level of training can act in a positive way that will affect the development of children in terms of selfdevelopment, individual development, perspective on the behavior of the child, and having knowledge about child education [15]. It can be anticipated that this situation will create environments that develop children's receptive and expressive language acquisition.

Although language acquisition generally follows the same order in all children, the pace of this development is also affected by the conversations in the social environment, the frequency of interactive speech with the child, the interaction with the individuals the child speaks to, and making use of technical and educational materials used in 
language teaching [29]. The environment and especially the richness of verbal stimuli offered to the child by the mother is an important variable in terms of language acquisition [27]. In this context, it can be stated that the child's language potential is affected by his/her social environment.

In this study, the PPVT language scores and vocabulary knowledge of the children in the experimental group have been evaluated with a pre-test, and then a significant increase has been observed in the post-test results after the parent training that has supported language acquisition. This increase is significantly higher than PPVT scores of children in the control group. According to this result, we can claim that parental training that supports language acquisition has a positive effect on language development in early childhood.

In this study, $55.8 \%$ of the children in the experimental group had two siblings, and $25.7 \%$ of them had more than two siblings. Considering the interest and time that parents will allocate to their children, if the number of individuals living together in the family is low, the interest towards the child is higher compared to the largely populated families [25]. Upon investigating language development and vocabulary, Jones and Plass (2002) have revealed that language development observed in children without siblings is more advantageous compared to the children with many siblings [17]. Havron, Ramus, Heude, Forhan, Cristia, and Peyre (2019) conducted a study on 1154 children and examined the effect of older siblings' age differences and gender on children's language development, and they found out that children with large age differences with their older sisters had better language skills than children with older brothers [26]. They have determined that children who have older sisters at home have better language skills than the children with older brothers. On the contrary to this study, Barnett (1988) states that the age difference between siblings and sibling gender is not related to language skills [36]. While having siblings seems like an advantage, other factors that affect language development may have a greater impact on having one child or more siblings. Considering that there may be intercultural differences on this subject, it is necessary to carry out studies with larger samples. In the face of the results of our study, we may state that what is important is the quality of the time spent for the development of the child's language acquisition and the development of vocabulary rather than the number of siblings.

In our study, the mean PPVT test scores were compared according to gender and number of siblings, and no difference was found between language development scores ( $p>0.05$ ). Freebody and Anderson (1983) emphasized that there was no significant difference by gender in terms of language development in children in their study, in which they examined the types of speech of children in early childhood [36]. In their study identifying the connection between language acquisition and social environment in babies, Ramirez Esparza, Garcia Sierra, and Kuhl (2014) found that girls and boys show similarities in terms of language development except for the first 18 months and that it changes in the following years. Thus it seems that there is a need for extensive and longitudinal studies on this subject [4].

When the post-test and retention test scores of our study group were examined, the values in the retention test of the experimental group were found to be higher. This result suggests that parental training that supports language acquisition is effective in our study, therefore parents sometimes are supposed to repeat language activities with their children. Contrary to our study, Muslugume (2016) detected lower scores in retention tests in their study, in which they examined the effect of parental training on the language development of children of families with low socioeconomic status. This situation can be interpreted as the fact that children were not engaged in activities that would affect their language skills during the summer period between the post-tests and the retention tests [21,27].

In our study, when parents' evaluations of training that supported children's language acquisition were examined, the parents stated that they felt a sense of belonging to the group they regularly participated in, and they highlighted the fact that their group was a team; Furthermore, they felt relieved because they were together with other parents who had the same problems. The fact that their children shared common aspects such as expanding their vocabulary, using the language correctly, and participating in the program in order to acquire a language quickly, and therefore the fact that they could understand each other better may have all been effective in their evaluation of the educational program positively.

When the general evaluations of the training program that strengthens the language acquisition applied to parents in our study were examined, it was determined that the parents had a positive attitude towards the training program. Regarding data obtained, the parents thought that the educational program reached its goals, they obtained positive gains from the content, they found the tools and materials used sufficient, and they were satisfied with the instructor. Similarly, in a study conducted by Sapungan and Sapungan (2014), they revealed that parental training had a positive effect on children's social and language development according to the measurements made immediately after and three months upon the training, and parents stated the training as successful [37]. The studies of Schwartz, Koh, Chen, Sinke, and Geva (2016) identified that the Parenting Training Program, which was applied to support parents in early childhood, provided progress in the developmental areas of the child, so it was asked to be repeated by the parents [38]. However, Desforges and Abouchaar (2003) emphasize that the fact that most Parenting Training Programs are made for a short time and only to improve behavior will not have long-term positive effects on children's behaviors [39].

In the PSP carried out within the scope of this study, the parents pointed out that the group process had a significant effect on their change. The parents felt a sense of belonging to the group they regularly participated in, and stated that they felt relieved due to the fact that there were other parents who were also willing to learn about language acquisition. The most important reason why this training is considered very useful by parents can be regarded as the fact 
that parents have similar concerns during the training process and the fact that they can understand each other in a better way.

\section{Conclusion \& Recommendations}

This study was conducted to evaluate the effect of a Parenting Training Program that supports language acquisition in early childhood.

8 weeks of training was given to the experimental group. Twice a week and 60 minutes of training were held each time. Games that increase parent-child interaction and language acquisition at home were recommended every day. Weekly homework was given to parents and children "together". The same training was given to teachers. Teachers did motivating activities that support parents every day. Feedback was received from parents and teachers each week, and new fixes and additions were made to the program based on their recommendations. In the last week of the program, teachers and parents were post-tested.

The results of this study show that parenting training that supports children's language acquisition has a positive effect on children's language development. In the study, some of the reasons affecting the language acquisition of normal children were examined, and the outcomes of training for parents affecting children's language development in the pre-school period were examined respectively. Parent education that supports language acquisition" in Turkey has been examined; Teaching techniques not done in other studies were used in this study. In this study; Many teaching techniques such as demonstration, case study, discussion, problem solving, brainstorming, fishbone, drama, child-tochild teaching, station technique were used. At the end of the research; Parents and teachers stated that these techniques have a very positive effect.

The proposed method is different from the methods used in other studies. The method was very effective as parents were also included in the study and homeschooling continued.

As a result of the research, it was revealed that parental support is very important in language acquisition, and an education given to parents contributes greatly to the child's language learning. Early childhood is the most critical period for children to grow and develop, when they are most open to all stimuli from outside. During this period, a good education to be given to families can provide the necessary environment for the healthy growth and development of children. Teaching by instructors alone is not sufficient in language teaching at an early age. Language-related activities should also be done in the home environment. Language activities with parents reinforce the child's learning of the language.

There was no significant difference between the Peabody Picture-Word Test pre-test language skill scores of the children in the experimental and control groups. However, a significant difference was found between the language skill mean scores after the parents of the experimental and control groups were given the training that seemed to have enhanced language acquisition. In other words, when parents in the experimental group are educated and support children's language acquisition, children's language acquisition appears to have been successful [40].

When the pre-test and post-test language skills regarding the arithmetic averages of the experimental and control groups are investigated, there is a certain increase revealed in the post-test scores of both groups compared to the pretest scores. This increase is lower in the control group compared to the experimental group.

Upon comparing the post-test and retention test language skill scores of the experimental group, we have revealed a positively significant difference. Therefore, we may assume that the language acquisition-supportive training program applied to parents has had impact on the experimental group.

Generally, after a child starts school, language acquisition turns into conscious learning mechanisms. After this stage, children gain the cognitive skills that adults possess in a similar way $[32,40]$. As language acquisition increases, an analytical and reflection-based learning process begins, and children develop the learning strategies through which they learn best.

As a result of this study, we have revealed that the training supporting parents contributes to language acquisition. The family environment, which makes a child feel a desire to learn a language and creates the appropriate environment by arousing curiosity in the child, provides a good level of language acquisition for the child. Parents should take into account the natural needs of the child and convince the child that he/she needs to know the language in order to participate in the planned fun activities or games. If the child wants to have fun with his / her friends and teachers, he/she will be willing to find out the language and feel an inner need for such a process [10]. It is important to provide language acquisition in a natural environment where children interact in their daily lives. Considering the age and developmental characteristics of the child, we should plan which words will be taught, as well as the activities to use such as games and puzzles. The factors such as being exposed to the language frequently, finding out new information constantly, the number of individuals communicated through the language, motivation of the child, interactive learning techniques, interaction rate with the individuals he/she talks with, the use of technical and educational materials utilized in language teaching are all quite important for language acquisition [36]; therefore, an appropriate training should be given to parents by taking these factors into account.

The study was conducted by a different method of field work done in Turkey. Education methods applied at school were continued at home as well. Thanks to the fun education, permanent learning has been achieved in children. The 
recommendations given to the parents were made under the control of academicians who have worked in this field for years. Three child development professors and two professors of language teaching who conducted inspections gave feedback on the effectiveness and efficiency of the study. This method will set an example for other field studies. All of the parents and teachers gave positive feedback. The reliability of the model used has been inspected by expert academicians.

The interactive teaching techniques used in this study had "very fast and permanent" effects on language acquisition. In Turkey, language teaching is also carried out at the university, starting with preschool theories. However, "fast and permanent learning" usually does not occur. The majority of the language learning population do not acquire the language, they memorize it. In this study; It has been demonstrated that language acquisition is "fast and permanent" when fun and very different techniques are used in the family and school environment.

The teaching techniques used in this research have contributed significantly to the field of child education in Turkey. The results of the research were presented to the National Education Directorates; An official letter was sent to other schools by the directorate, and teachers were recommended to use these techniques. A master thesis using these techniques is being prepared. The success achieved in this research is an example for other theses and projects.

In conclusion, language acquisition at an early age has positive effects. A properly structured language education, in which the developmental characteristics of the child are taken into account, contributes positively to the cognitive development of the child. From an early age, emphasis should be placed on using the language fluently and the process should schedule in accordance with the relevant rules

\section{References}

[1] May Y. Fan. "Frequency of Use, Perceived Usefulness, and Actual Usefulness of Second Language Vocabulary Strategies: A Study of Hong Kong Learners", Modern Language Journal, Vol.87, No.2, pp.222-241, 2003.

[2] Nurcan Kocak, Busra Ergin, Hatice Yalcin. "60-72 Aylik Cocuklarin Turkçe Dil Kullanim Duzeyleri ve Etki Eden Faktorlerin Incelenmesi" [Examining the Turkish Language use Levels of 60-72 Month-Old Children and the Factors Affecting Them], KMU Sosyal ve Ekonomik Arastirmalar Dergisi, Vol.16, No.2, pp.100-106, 2014.

[3] Natália Brunnet, Cristina Portugal,"Digital Games and Interactive Activities: Design of Experiences to Enhance Children Teaching-Learning Process", International Journal of Modern Education and Computer Science(IJMECS), Vol.8, No.12, pp.19, 2016.DOI: 10.5815/ijmecs.2016.12.01

[4] N. Ramirez Esparza, A. Garcia Sierra, P. Kuhl. "Look Who's Talking: Speech Style and Social Context in Language Input to Infants are Linked to Concurrent and Future Speech Development”, Developmental Science, Vol.17, No.6, pp.880-891, 2014. DOI: $10.1111 /$ desc.12172.Look

[5] Kelly Bridges and Eva Hoff. "Older Sibling Influences on the Language Environment and Language Development of Toddlers in Bilingual Homes", Applied Psycholinguistics, Vol.35, No.2, pp.225-241, 2014. DOI: 10.1017/S0142716412000379

[6] Ari Brown, "Media Use by Children Under than 2 Years", Pediatrics, Vol.128, No.5, pp.1040-1045, 2011.

[7] Yusheng Ying, Wei Lv. "A Study on Higher Vocational College Students' Academic Procrastination Behavior and Related Factors". International Journal of Education and Management Engineering(IJEME), Vol.7, pp.29-35, 2012, DOI: 10.5815/ijeme.2012.07.05

[8] Saville Troike. "Introducing Second Language Acquisition”. New York: Cambridge University Press. 2006

[9] M. Eriksson, P. Marschik, T. Tulviste, M. Almgren, M. Perez Pereira, S. Wehberg, "Differences between Girls and Boys in Emerging Language Skills: Evidence from 10 Language Communities", British Journal of Developmental Psychology, Vol.30, No.2, pp.326-343, 2012. DOI: 10.1111/j.2044-835X.2011.02042.x

[10] Janellen Huttenlocher, Wendy Haight, Anthony Bryk, Michael Seltzer, Thomas Lyons, "Early Vocabulary Growth: Relation to Language Input and Gender", Developmental Psychology, Vol.27, No.2, pp.236- 248, 1991. DOI: 10.1037/0012-1649.27.2.236

[11] V. Inci Kavak, "The Acquisition and Use of Negation in the Early Child Language", Journal of Language and Linguistic Studies, 2019, 15(2), 587- 604. DOI: 10.17263/jlls.586745

[12] Murat Demirekin, "Yabanci Dil Olarak Turkçenin Anlamlandirilmasinda Kelime ve Dil Ogrenme Stratejileri Kullanimi" [Using Vocabulary and Language Learning Strategies in Comprehending Turkish as a Foreign Language]. pHd thesis, Hacettepe University Language Learning Department. Ankara. 2017.

[13] Attapol Khamkhien, "Factors Affecting Language Learning Strategy Reported Usage by Thai and Vietnamese EFL Learners", Electronic Journal of Foreign Language Teaching, Vol.7, No.1, pp. 66-85, 2010.

[14] Lev Vygotsky, "Dusunce ve Dil" [Thought and language] (Çev. Semih Koray), Istanbul: Toplumsal Donusum Yayinlari. 1998.

[15] Hatice Yalcin, "Çocuk Gelisimi”" [Child Development], Ankara: Nobel Publishier. 2010

[16] Abdullah Gharbavi, Seyyed Mousavi. "Do Language Proficiency Levels Correspond to Language Learning Strategy". Adoption, English Language Teaching, Vol.5, No.7, pp. 110- 122, 2012.

[17] Linda Jones, \& Jan Plass, "Supporting listening comprehension and vocabulary acquisition with multimedia annotations". The Modern Language Journal, Vol.86, No.1, pp.546-561, 2002.

[18] Olugbenga Adejo, Isaiah Ewuzie, Abel Usoro \& Thomas Connolly, "E-Learning to m-learning: Framework for data Protection and Security in Cloud Infrastructure", International Journal of Information Technology and Computer Science (IJITCS), Vol.10, No.4, pp.1-9, 2018. DOI: 10.5815/ijitcs.2018.04.01

[19] Kolo David Kolo, Solomon A Adepoju, John Kolo Alhassan, "A decision tree approach for predicting students academic performance", International Journal of Education and Management Engineering (IJEME), Vol.5, No.5, pp.12-19, 2015. DOI: 10.5815/ijeme.2015.05.02. 
[20] Marianne Nikolov, “Why Do You Learn English, Because the Teacher is Short, a Study of Hungarian Children's Foreign Language Learning Motivation", Language Teaching Research, Vol.3, No.1, pp.33-56, 1999. DOI: $10.1191 / 136216899670790538$.

[21] Jean Piaget, "Çocukta Zihinsel Gelisim" [Mental Development in a Child] (Çev. Huseyin Portakal). Istanbul: Cem Publisher. 2000

[22] Sercan Uztosun, "The Impact of Language Experience on Language Learner Strategy Use in Turkish EFL context. International Journal on Trends in Education and Their Implications, Vol.5, No.1, pp.157-168, 2014.

[23] Richard Gershon, Karon Cook, Dan Mungas, Jennifer Manly, Jerry Slotkin, Jennifer Beaumont, Sandra Weintraub, 'Language measures of the NIH Toolbox Cognition Battery", Journal of the International Neuropsychological Society, Vol.20, No.6, pp.642-651, 2014. DOI: 10.1017/S1355617714000411.

[24] Joyce Epstein, Mavis Sanders, Beth Simon, Karen Salinas, Natalie Jansorn, "School, Family, and Community Partnerships: Your Handbook For action" (2nd ed.). Thousand Oaks, CA: Corwin Press 2002.

[25] N. White, R. Ensor, A. Marks, L. Jacobs, C. Hughes, "It's Mine, Does Sharing with Siblings at Age 3 Predict Sharing with Siblings, Friends, and Unfamiliar Peers at Age 6", Early Education and Development, Vol.25, No.2, pp.185-201, 2014. DOI: 10.1111/j.1469-7610.2010.02276.x

[26] Naomi Havron, Franck Ramus, Barbara Heude, Anne Forhan, Jan Alejandrina, "The Effect of Older Siblings on Language Development as a Function of Age Difference and Sex", Vol.2, pp.36-47, 2019. DOI: 10.31234/osf.io/fgpmd.

[27] Chih Chang \& Hui Liu, "Language Learning Strategy Use and Language Learning Motivation of Taiwanese EFL University Students", Electronic Journal of Foreign Language Teaching, Vol.10, No.2, pp.196-209, 2013.

[28] J. Huttenlocher, M. Vasilyeva, H. R. Waterfall, J. Vevea, L. Hedges., "The Varieties of Speech to Young Children", Developmental Psychology, Vol.43, No.5, pp.1062-1083, 2007. DOI: 10.1037/0012-1649.43.5.1062

[29] Robert Zajonc \& Greg Markus, "Birth Order and Intellectual Development", Psychological Review, Vol.82, No.1, pp.74-88. 1975. DOI: $10.1037 / \mathrm{h} 0076229$

[30] Jeremy Baumberg, "Bilim Nedir ve Bilimsel Arastirma Nasil Yapilir" [What is science and how to do scientific research] (Çev: Murat Demirekin). Princeton University. Konya: Egitim Yayinevi. 2020

[31] Kay Lopez \& Danny Willis, "Descriptive Versus Interpretive Phenomenology: Their Contribution to Nursing Knowledge", Quality Health Research, Vol.14, No.1, pp.726-735, 2004.

[32] Lloyd Dunn, "Peabody Picture Vocabulary Test". Circle Pines, Toronto: Guidance Service. 1959

[33] Jerrold Katz, Feyiz Onen, Nermin Demir, Aliye Uzunkaya, Perihan Uludag, "Turkish Peabody Picture-Vocabulary Test", Hacettepe Sosyal ve Beseri Bilimler Dergisi. Vol.6, No.1, pp.129-140, 1984.

[34] Ramazan Ari, Engin Deniz, Yavuz Erisen, Nadir Çelikoz, "Çocukların Okula Hazırlanması (Anne-Çocuk Egitimi) Temel Arastirmasi”, Milli Egitim Bakanligi Projeler Koordinasyon Merkezi Baskanligi [Preparing children for school (mother-child education) basic research, Ministry of National Education Projects Coordination Center] Ankara. 2006

[35] Marva Barnett, "Reading Through Context: How Real and Perceived Strategy Use Affects L2 Comprehension", The Modern Language Journal, Vol.72, No.1, pp.150-162, 1988.

[36] Peter Freebody \& Richard Anderson, "Effects on Text Comprehension of Different Proportions and Locations of Difficult Vocabulary", Journal of Reading Behavior, Vol.15, No.1, pp.19-23, 1983.

[37] Gina Sapungan \& Ronel Sapungan, "Parental Involvement in Child's Education: Importance, Barriers And Benefits", Asian Journal of Management Sciences and Education, Vol.3, No.2, pp.42-48, 2014.

[38] Mila Schwartz, Poh Wee Koh, Xi Chen, Mark Sinke, Esther Geva, "Through the Lens of Teachers in Two Lingual Programmes: a Look at Early Lingual Education”, Language, Culture and Curriculum, Vol.29, No.2, pp.141-168, 2016. DOI: 10.1080/07908318.2015.1103250

[39] Ali Javed \& Rabeea Islam, “An Intelligent Alarm and Messaging Based Surveillance System for Fall Detection and Absence Recognition of Unaccompanied Child”, International Journal of Image, Graphics and Signal Processing(IJIGSP), Vol.3, pp.48-54, 2013. DOI: 10.5815/ijigsp.2013.03.07

[40] Hugo Peyre, Jonathan Bernard, Nicolas Hoertel, Anne Forhan, Marie Charles, “ Cognitive Development Differential Effects of Factors Influencing Cognitive Development at the Age Of 5-To-6 years”, Cognitive Development, Vol.40, pp.152-162, 2016. DOI: $10.1016 /$ j.cogdev.2016.10.001

[41] Barbara Heude \& Anne Forhan, "Profile: The EDEN Mother-Child Cohort on the Prenatal and Early Postnatal Determinants of Child Health and Development", International Journal of Epidemiology, Vol. 45, No.2, pp.353-363, 2016. DOI:10.1093/ije/dyv151

\section{Authors' Profiles}

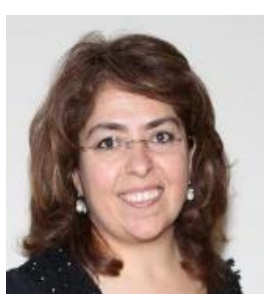

Dr. Hatice Yalcin- (Turkey, Konya) - (Asst. Assoc. Dr. Karatay University Head of Department of Child Development in Turkey). She is doing research on child education, family education and language development. She is the director of the Child Education Application Center. She has acted as a consultant for numerous master theses on language acquisition. 


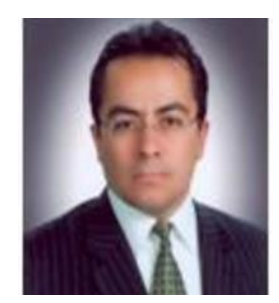

Dr. Murat Demirekin- (Turkey, Konya)- (PhD at Hacettepe University, Department of Language Education in Turkey). He conducts research in the field of language acquisition and language teaching. He has translated many books. He organizes trainers training courses. He has acted as an executive in national and international projects on language acquisition.

How to cite this paper: Hatice Yalcin, Murat Demirekin, " Training Program Supporting Language Acquisition", International Journal of Modern Education and Computer Science(IJMECS), Vol.13, No.3, pp. 1-12, 2021.DOI: 10.5815/ijmecs.2021.03.01 